\title{
MEMAHAMI PANGKAT, AKAR, LOGARITMA DAN DERET
}

\author{
Marwita \\ 9193490310001 \\ STKIP YAPTI JENEPONTO \\ Marwita190921@gmail.com ${ }^{1}$, Ithamarwita@gmail.com²
}

\begin{abstract}
ABSTRAK
Tulisan ini bertujuan untuk meningkatkan kemampuan pembelajaran mahasiswi untuk lebih memahami materi yang berpangkat melalui berbasis pembelajaran daring. Kegiatan yang dilakukan adalah (1) memahami tentang belajar matematika yaitu bilangan berpangkat salah satunya pangkat bulat positif dan pangkat bulat negatif (2) melakukan pemahaman kegiatan pembelajaran daring tentang akar (3) Memahami tentang logaritma yang merupakan juga bentuk perpangkatan (4) memahami tentang deret bila suku pada suatu banjar di jumlah maka jumlahnya di namakan deret. Sebagian besar siswi mampu memahami materi pangkat akar logaritma dan deret melalui pembelajaran daring.
\end{abstract}

KATA KUNCI: Akar, Deret, Memahami, Pangkat, Logaritma. 


\section{PENDAHULUAN}

Matematika merupakan ilmu yang mempelajari hubungan suatu pola, bentuk dan struktur. Penyebab matematika sulit dipelajari adalah ciri khas matematika yang menggunakan simbol, dan mengandalkan nalar, serta hanya dipandang sebagai produk yang ada. Padahal pada kenyataannya, pemahaman konsep merupakan suatu hal yang sangat penting dalam menyelesaikan soal-soal matematika, serta mampu mengaplikasikannya dalam dunia nyata.

Berdasarkan pengalaman mengajar, peneliti masih banyak menjumpai mahasiswa yang mendapatkan nilai dibawah C (56-62). Kalkulus merupakan salah satu cabang matematika dengan berfokus ide dasar yang berpusat pada huruf, rumus, grafik, serta pengembangannya (aplikasi) pada kehidupan sehari-hari. Secara khusus, dalam mempelajari kalkulus sangat diperlukan sejumlah materi dasar matematika, seperti aljabar, geometri dan trigonometri yang harus dipahami konsepnya dan tidak hanya menghafal rumus. Kebiasaan hanya menghafalkan rumus, mengakibatkan mahasiswa lupa dan tidak dapat menguasai materi dasar yang merupakan syarat pembelajaran materi selanjutnya. Mahasiswa yang tidak memahami proses terbentuknya rumus, serta tidak membaca buku yang berkaitan dengan pembelajaran akan mengalami kesulitan dalam mengembangkan penguasaan dasar pembelajaran. Selanjutnya juga akan berpengaruh dalam meningkatkan kemampuan memahami konsep pembelajaran. (Farah Indrawati dkk, 2017)

\section{HASIL DAN PEMBAHASAN}

\section{a. Bilangan Pangkat}

Tahukah Anda, berapa jarak antara matahari dan bumi? Ternyata jarak antara matahari dan bumi adalah $150.000 .000 \mathrm{~km}$. Penulisan jarak antara matahari dan bumi dapat ditulis dengan bilangan pangkat. Bagaimana caranya?

Pangkat bilangan bulat dapat berupa bilangan bulat positif, nol, atau negatif.

1. Pangkat Bulat Positif

- Pengertian Pangkat Bulat Positif

Jika a adalah bilangan riil dan $\mathrm{n}$ bilangan bulat positif maka an (dibaca "a pangkat $\mathrm{n} "$ ) adalah hasil kali $\mathrm{n}$ buah faktor yang masing-masing faktornya adalah a. Jadi, pangkat bulat positif secara umum dinyatakan dalam bentuk. (Un Smk, 2006)

$$
\mathrm{A}^{\mathrm{n}}=\underbrace{\operatorname{ax} \text { ax ax }}_{\text {Sebanyak n faktor }}
$$

dengan: $\mathrm{a}=$ bilangan pokok (basis);

$\mathrm{n}=$ pangkat atau eksponen;

an = bilangan berpangkat.

Contoh Soal:

Tentukan nilai dari pemangkatan berikut.
a. $3^{4}$
b. $[-1]^{7}$

Jawab :

a. $3^{4}=3 \times 3 \times 3 \times 3=81$

b. $[-1]^{7}=[-1] \times[-1] \times[-1] \times[-1] \times[-1] \times[-1] \times[-1]=-1$ 
2. Bilangan Berpangkat Negatif

Untuk $\mathrm{a} \in \mathrm{R}$ dan $\mathrm{a} \neq 0$ didefinisikan:

$$
\mathrm{a}^{-\mathrm{n}}=\frac{1}{\mathrm{a}^{\mathrm{n}}}
$$

Definisi ini berasal dari bentuk berikut.

Misalkan $\mathrm{a}^{\mathrm{m}}: \mathrm{a}^{\mathrm{m}+\mathrm{n}}=\mathrm{a}^{\mathrm{m}-[\mathrm{m}+\mathrm{n}]}=\mathrm{a}^{-\mathrm{n}}$

$$
\mathrm{A}^{\mathrm{m}}: \mathrm{a}^{\mathrm{m}+\mathrm{n}}=\frac{\mathrm{a}^{\mathrm{m}}}{\mathrm{a}^{\mathrm{m}} \mathrm{a}^{\mathrm{n}}}=\frac{1}{\mathrm{a}^{\mathrm{n}}}
$$

maka $\mathrm{a}^{-\mathrm{n}}=\frac{1}{\mathrm{a}^{\mathrm{n}}}$

Contoh Soal :

Nyatakan bilangan-bilangan berpangkat di bawah ini ke dalam pangkat negatif.
a. $\mathrm{a}^{4}$
b. $x^{3} y^{2}$
c. $\frac{1}{\mathrm{P}^{5} \mathrm{q}^{2}}$

Jawab :
a. $\mathrm{a}^{4}=\frac{1}{\mathrm{a}^{-4}}$
b. $\mathrm{X}^{2} \cdot \mathrm{y}^{2}=\frac{1}{\mathrm{x}^{-3}} \frac{1=}{\mathrm{y}^{-2}} \frac{1}{\mathrm{x}^{-3} \mathrm{x} \mathrm{y}^{-2}}$
c. $\frac{1}{\mathrm{P}^{5} \mathrm{q}^{2}}=\frac{1}{\mathrm{p}^{5}}{ }^{1} \frac{1}{\mathrm{q}^{2}}=\mathrm{p}^{-5} \cdot \mathrm{q}^{-2}$

\section{b. Akar}

Kaidah-kaidah perpangkatan untuk an pada bab sebelumnya dinyatakan untuk nilai a yang tidak sama dengan nol dan $\mathrm{n}$ merupakan bilangan bulat positif atau negatif. Sesungguhnya nilai $\mathrm{n}$ pada bentuk an dapat berupa setiap bilangan rasional. Ingat, bilangan rasional adalah sembarang bilangan yang dapat ditunjukkan oleh pembagian dua bilangan bulat $\mathrm{p} / \mathrm{q}$, untuk $\mathrm{q} \neq 0$ serta $\mathrm{p}$ dan $\mathrm{q}$ merupakan bilangan bulat.

Pengembangan kaidah-kaidah perpangkatan untuk pangkat suatu bilangan pecahan (yaitu bilangan rasional) menghendaki agar bentuk $\mathrm{a}^{\mathrm{p} / \mathrm{q}}$ didefinisikan sesuai dengan kaidahkaidah perpangkatan yang berlaku. Misalnya ada suatu ekspresi dalam bentuk $\mathrm{a}^{1 / \mathrm{n}}$ dan berlaku kaidah $\left(\mathrm{a}^{\mathrm{m}}\right)^{\mathrm{n}}$ maka dengan menganggap $\mathrm{m}=1 / \mathrm{n}$ akan berlaku pula:

$$
\left(a^{1 / n}\right)^{n}=a^{n / n}=a
$$


Bentuk $\mathrm{a}^{1 / \mathrm{n}}$ disebut akar pangkat $\mathrm{n}$ dari a dan disimbolkan $\sqrt[n]{\mathrm{a}}$

Contoh:

(a) $a^{1 / 2}$ menunjukkan akar kuadrat dari a atau hanya disebut akar dari a dan ditulis $\sqrt[2]{\mathrm{a}}$ atau hanya $\sqrt{\mathrm{a}}$.

(b) $\mathrm{a}^{1 / 3}$ menunjukkan akar pangkat tiga dari a dan ditulis $\sqrt[3]{\mathrm{a}}$.

(c) $\mathrm{a}^{3 / 4}$ menunjukkan akar pangkat empat dari a pangkat tiga dan ditulis $\sqrt[3]{\mathrm{a}^{4}}$.

Seperti telah disebut di atas, bentuk $\mathrm{a}^{1 / 2}$ dapat ditulis menjadi a dan $\mathrm{a}^{1 / \mathrm{n}}$ dapat ditulis

$\sqrt[n]{a}$. Lebih umum lagi untuk bentuk $\mathrm{a}^{\mathrm{m} / \mathrm{n}}$ dapat ditulis menjadi:

$a^{m / n}=\sqrt[n]{a^{m}}$

Kaidah-kaidah akar

$$
\begin{aligned}
& \sqrt[m]{a^{n}}=a^{n / m} \\
& m \sqrt{a \cdot b}=\sqrt[m]{a \cdot m} \sqrt{b} \\
& m \sqrt{a=}=a^{1 / m} \\
& \sqrt[m]{\sqrt{n} a}=\sqrt[m]{n} \sqrt{a}
\end{aligned}
$$

\section{c. Logaritma}

Logaritma merupakan bentuk perpangkatan juga. Secara definisi, logaritma menunjukkan pangkat yang dimiliki oleh suatu basis sehingga bentuk perpangkatan itu nilainya sama dengan bilangan tertentu. Dengan menggunakan simbol, maka bila ada:

$$
\mathrm{y}=\mathrm{a}^{\mathrm{n}} \text { untuk } \mathrm{a}>0 \text { dan } \mathrm{a} \neq 1
$$

maka $\mathrm{n}$ merupakan logaritma dari y dengan basis a atau ditulis:

$$
\mathrm{n}={ }^{\mathrm{a}} \log \mathrm{y}
$$

\section{Kaidah-kaidah Logaritma}

Untuk setiap bilangan riil positif $\mathrm{x}$ dan $\mathrm{y}$, setiap bilangan riil $\mathrm{r}$ dan bilangan riil positif $\mathrm{b}=1$, berlaku:

(1) ${ }^{a} \log x \cdot y={ }^{a} \log x+{ }^{a} \log y$

(2) ${ }^{a} \log x / y={ }^{a} \log x-{ }^{a} \log y$

(3) ${ }^{a} \log x r=r{ }^{a} \log x$

(4) ${ }^{a} \log x={ }^{a} \log b \cdot{ }^{b} \log x$

(5) ${ }^{a} \log b \cdot{ }^{b} \log a=1$ atau $\left({ }^{a} \log b\right)=\frac{1}{\left({ }^{b} \log a\right)}$

(6) ${ }^{a} \log a=1$

(7) ${ }^{a} \log 1=0$

\section{d. Deret}

Bila suku-suku pada suatu banjar dijumlah, maka jumlah tersebut dinamakan deret. Jadi deret merupakan penjumlahan semua suku suatu banjar. Seirama dengan pembedaan banjar, maka deret dapat dibedakan menjadi deret hitung, deret ukur dan deret harmoni. Deret hitung merupakan jumlah suku-suku banjar hitung, deret ukur merupakan jumlah suku-suku banjar ukur dan deret harmoni merupakan jumlah suku-suku banjar harmoni. (Nuryanto St, 2017) 
Contoh :

a. Deret hitung : $1+2+3+\ldots+n$

b. Deret ukur : $5+10+20+. .+5\left(2^{\mathrm{n}-1}\right)$

c. Deret harmoni: $1+\underline{1}+\underline{1}+\ldots+\underline{1}$

$$
23 \mathrm{n}
$$

Karena sampai saat ini belum diketemukan rumus untuk menjumlahkan deret harmoni, maka untuk selanjutnya deret harmoni tidak akan dibahas. Secara umum suatu deret dapat ditulis sebagai:

$\mathrm{J}_{\mathrm{n}}=\mathrm{a}_{1}+\mathrm{a}_{2}+\mathrm{a}_{3}+\ldots+\mathrm{a}_{\mathrm{n}}$

Deret ukur dan deret hitung sering digunakan dalam matematika ekonomi. Sebagai Contoh, Malthus, seorang ahli ekonomi teori, pernah menyatakan bahwa penduduk mempunyai kecenderungan untuk tumbuh seperti deret ukur, sedangkan bahan makanan tumbuh menurut deret hitung. Anda telah mengenal deret ukur dan deret hitung, maka pernyataan Malthus tersebut mengandung arti bahwa pertumbuhan penduduk sangat cepat dan lebih cepat dibanding pertumbuhan makanan. Apabila a adalah suku pertama suatu banjar dan $b$ adalah beda antara dua suku yang berurutan, maka sesuai dengan pengertian deret hitung:

$$
\begin{aligned}
& \text { suku pertama }=a \\
& \text { suku kedua }=a+b \\
& \text { suku ketiga }=a+2 b \\
& \text { suku keempat }=a+3 b \\
& \text { suku ke } n=a+(n-1) b=S n
\end{aligned}
$$

Jadi suku ke n suatu banjar hitung, ditentukan oleh

$\mathrm{S}_{\mathrm{n}}=\mathrm{a}+(\mathrm{n}-1) \mathrm{b}$

Deret hitung jumlahnya dapat dihitung dengan menggunakan rumus:

$$
\mathrm{J}=\frac{1}{2} \mathrm{n}\left(\mathrm{a}+\mathrm{S}_{\mathrm{n}}\right)
$$

di mana $\mathrm{n}=$ banyaknya suku

$$
\begin{aligned}
\mathrm{a} & =\text { suku pertama } \\
\mathrm{Sn} & =\text { suku ke } \mathrm{n}
\end{aligned}
$$

Contoh

Jika ingin mengetahui suku ketujuh suatu banjar hitung yang suku pertamanya $=1$ dan beda $=2$ adalah:

$$
\begin{aligned}
S_{n} & =a+(n-1) b \\
& =1+(7-1) 2 \\
& =13
\end{aligned}
$$

Deret hitung dengan jumlah tujuh suku tersebut adalah:

$$
\begin{aligned}
\mathrm{Jn} & =\frac{1}{2} \mathrm{n}(\mathrm{a}+) \mathrm{S}_{\mathrm{n}} \\
\mathrm{J} 7 & =\frac{1}{2} 7(1+13) \\
& =49
\end{aligned}
$$


Selain banjar hitung, kita telah mengenal banjar ukur. Suatu banjar ukur ditandai oleh banjar yang hasil bagi suatu sukunya dengan suku sebelumnya merupakan bilangan konstan. Atau suku suatu banjar ukur diperoleh dari hasil kali suku sebelumnya dengan suatu pengali yang besarnya konstan. Bila suatu banjar ukur memiliki suku pertama a dan pengali sebesar p, maka secara matematis dapat ditulis:

suku pertama $=\mathrm{a}$

suku kedua $=$ ap

suku ketiga $=\mathrm{ap}^{2}$

suku ke $n=\operatorname{ap}^{\mathrm{n}-1}=\mathrm{S}_{\mathrm{n}}$

Jadi suku ke n suatu banjar ukur ditentukan oleh $S_{n}=a p^{n-1}$

Jumlah n suku suatu banjar ukur dapat ditentukan dengan rumus

$$
J=a \frac{1-p^{n}}{1-p}=\frac{a-p s}{1-p}
$$

Rumus di atas tidak berlaku untuk $\mathrm{p}=1$. Pada kasus $\mathrm{p}=1$, telah diketahui bahwa satu dipangkatkan berapa saja hasilnya adalah satu, sehingga suku ke $\mathrm{n}$ nilainya akan sama dengan suku pertamanya. Sehingga jumlah $n$ sukunya sama dengan hasil kali antara a dengan n. Bila $\mid \mathrm{p} k 1$ dan jumlah sukunya tak terhingga, maka jumlahnya dihitung dengan menggunakan rumus:

$$
\mathrm{J}=\frac{\mathrm{a}}{1-\mathrm{p}}
$$

\section{e. Kesimpulan}

Berdasarkan dari pemahaman materi yang ada di atas saya simpulkan bahwa matematika bilangan berpangkat yaitu bilangan pangkat negatif dan bilangan pangkat positif. Dan akar merupakan salah satu metode yang dapat meningkatkan kemampuan sehingga kita dapat mudah untuk memahaminya, cara cepat memahami pangkat dan akar memiliki prosedur yang mudah dalam pengerjaannya yaitu dengan adanya bilangan pokok, bilangan pangkat dan hasil perpangkatan. Logaritma merupakan bentuk perpangkatan juga, Secara definisi, logaritma menunjukkan pangkat yang dimiliki oleh suatu basis sehingga bentuk perpangkatan itu nilainya sama dengan bilangan tertentu, Bila suku-suku pada suatu banjar dijumlah, maka jumlah tersebut dinamakan deret. Jadi deret merupakan penjumlahan semua suku suatu banjar. 


\section{DAFTAR PUSTAKA}

Herianto, H., \& Hamid, N. (2020). Analisis Proses Berpikir Kreatif Dalam pemecahan Masalah Geometri Berdasarkan Gaya Kognitif Reflektif Dan Impulsif Siswa. Pedagogy: Jurnal Pendidikan Matematika, 5(2), 38-49. [online].

Herianto, H. (2020). Teknik Menulis Artikel Konseptual. [online].

Indrawati, Farah. (2017). Peran Penguasaan Dasar Matematika Dan Persepsi Mahasiswa Terhadap Kemampuan Pemahaman Konsep Mata Kuliah Kalkulus I. [online].

Jusmiana, A., Herianto, H., \& Awalia, R. (2020). Pengaruh Penggunaan Media Audio Visual Terhadap Hasil Belajar Matematika Siswa Smp Di Era Pandemi Covid-19. Pedagogy: Jurnal Pendidikan Matematika, 5(2), 1-11. [online]

Smk, Un. (2006). Bentuk Pangkat, Akar, dan Logaritma. [online]

St, Nuryanto. (2017). Matematika Bisnis. [online]. 